\title{
Non-Compliance With Study Drug
}

National Cancer Institute

\section{Source}

National Cancer Institute. Non-Compliance With Study Drug. NCI Thesaurus. Code C49631.

An indication that a subject has not agreed with or followed the instructions related to the study medication. 